\title{
Foliar application of Indol Acitic Acid (IAA) and Gebirilic acid (GA3) as well as interaction effect on growth yield and some physiological compositions of Triticum plant grown under salinity conditions
}

\author{
Gherroucha, H., fercha,A and Ben mekhlouf, Z \\ Department of Natural Science, Faculty of Sciences, Route of Ain El Bey, Mentouri \\ Constantine University, Algeria.
}

\begin{abstract}
The present study aimed to investigate the effect of spraying with IAA and GA3 and the interaction between them on improvement the growth, yield and some biochemical and physiological characteristics of wheat plant (Triticum durum serf Triticum aestivum) of two cultivars, Mohamed Ben Bachir (MBB) and Hedab (HD), were growing under different concentrations of sea water salinity ( $10 \%, 30 \%$ and $60 \%)$ and the comparison plant control was also used.The results showed decreased continuously in plant length and yield (as spikes and 100 wheat grain weight), with increasing the concentrations of salinity during the growth period, compared with untreated plants. The concentrations of salinity used, has negatively effect on number of leaves and proliferate (first generation) and the leaf area of plant. On contrast, proline content was increased with increasing the concentrations of salinity, this revealed that the plant exhibited resistant to salinity. The spraying with regulators of growth used in the present study (IAA and GA3), showed significant effect on plant, in the extent of reducing the hurt effect of salinity on the vegetative measurements and some physiological components of plant.
\end{abstract}

Keywords: Foliar application, Indol Acitic Acid (IAA) and Gebirilic acid (GA3)

\section{INTRODUCTION}

Cereals cultivation have occupy an important location among the agricultural crops all over the world. Wheat and barely are considered the two main crops from grain crops, specially in the aired zones, that depend on rains in the cultivation. Wheat was used as food from last hundred years ago due to their long association with man's food. Therefore, it was cultivated in large scales in the world to cope the increasing need for food and feed of the people. Therefore, it is necessary for stimulated the interest of scientists, who works in the field of studying wheat plant, to confirm these studies. Many cultivars having higher productivity and resistant for diseases were recently selected by some workers [2 ]; [4 ] and [14] .

The slime to clay loam soils, that contain suitable amounts of calcium and wastes and having neutral $\mathrm{pH}$, is suitable soil for wheat cultivation [3 ] ; [8 ]; [1 ] and[22 ] The cultivation of wheat is wide spread in the east of Algeria by using the systems of arid cultivation and also less information about the scientific methods are known. The newly method, that leads to hold up the wheat plant for growing in salinity medium was not used, particularly that the Algeria posses large regions and areas for cultivation, but it is salinity. Since it was necessary for using these large areas for increase the areas of wheat cultivation to obtained high yield under these conditions. Different realys were illustrated based on experimental studies on the effect of oxin and other ameliorative growth, specially IAA that cause very slightly effect and required easily and presented in places of there effect to continue the growth occuring [20], who indicated that the externally addition of IAA could be stimulate the synthesis of newly protein and RNA in Rhoeo leaves and yeast cells [22 ] and in sections of green pea stem and outer shell of bean endocarp [18 ], and in the section of Oat coleoptile elytrum cells [12 ]. Similar effect of both oxin and gebirilin (IAA and GA3), for enhances, elongation of cell, formation of partinocarpy fruits and combial activity and building of protein and nucleic acids (RNA and DNA) were reported by [10 ], [16 ].

The addition of IAA and GA3 individually having no effect, while the addition of both together to the plant ecology, lead to significant synergistic effect on the elongation of phalangidae [12 ], who reported that GA3 depend on IAA in appearance of their effect.

The present study aimed to knowledge the scientific methods that must be apply to make wheat plant become more resistant to higher concentrations of salinity by treatments with ameliorative growth. It 
aimed also to decrease the effect of salinity on yield. Since, the effect of spraying with IAA and GA3 at the level of $2 \%$ on the morphological and physiological characteristics of wheat plant grown under salinity conditions were also studied.

\section{MATERIALS AND METHODS}

The present study was done at plastic house in branch of lead, Idepartment of Natural Science, Faculty of Science, route of Ain El-Bey, Mentouri Constantine University, Algeria and Biochemistry Department, National Research Center, Cairo, Egypt.

Wheat seeds were obtained from experimental laboratory field, El-Khroub, Constantine, Algeria. Two cultivars were selected, the first was solid, Mohamed Ben Bachir (MBB) and the second was wet, Hedab (HD). Both cultivars are locally developed, having ability for growing under cold and airdity conditions.

Soil samples from the surface layer were taken and used for chemical and physical analyses. Total percentages of $\mathrm{CaCO}_{3}$ (Calcium carbonate), $\mathrm{pH}$ degree for saturated paste soil, and the degree of electrical conductivity of their extraction by $\mathrm{ml} \mathrm{mol} / \mathrm{cm}$ at $25^{\circ} \mathrm{C}$ were determined according to the method of [17 ] and [3 ]. The active carbonate and bicarbonate $\left(\mathrm{CO}_{3}\right.$ and $\left.\mathrm{HCO}_{3}\right)$ and Soil thickner were estimated by pipett method known as [11 ] method (1949), that described by[13]. The experiment was designed to contains four treatments of sea water salinity (0\%,10\%,30\%and 60\%), two levels of ameliorative growth (IAA and GA3) and two cultivars of wheat plant (MBB and HD). Each treatment was repeated for 3 times and thus, the experiment included 48 experimental units. The pots were filled with soil and cultivated by seeds of both cultivars under the present study (MBB and HD). The experiment was carried out under the watched over the vegetative stage, then, the measurements were recorded after 45 day of cultivation (during vegetative period of plant). During this period, the plant were exposed to irrigation with salinity 4 times according to the concentrations under the present study. Then, the mean of the principle stem length height of plant, number of leaves and proliferate and leaf area were recorded. Chemical analyses of vegetative period were done by determination of water potential of leaves according to the method described by [5]. The chlorophylls ( $a$ and $b$ ) were estimated by the method of[6 ] .

The growth of plants was follow till the fruiting period, then the plants were removed from the pots and the sum of root was separated from the sum of vegetative and spikes were isolated from plants, then the grains were isolated from the spikes and the spikes and 100 wheat grain weight were determined. Wheat grains were dryed, then milled by milling to very fine powder and used for estimation of nucleic acids content (RNA and DNA) according to the method of[15 ] and [9 ] .

\section{RESULTS AND DISCUSSIONS}

Soil analyses: Results in table(1) showed the experimental soil was calcareous soil ( contain $11.0 \%$ $\mathrm{CaCO}_{3}$ and has $\left.8.6 \% \mathrm{pH}\right)$ as [2 ] and [1 ] who reported that the soils contain $8 \%$ or more of total $\mathrm{CaCO}_{3}$ are identified as calcareous soil. The mechanical analysis of soil indicated that the soil was sand silt soil due to it contains $2.4 \mathrm{ml} \mathrm{mol}$ of salt $/ \mathrm{cm}$ which are within the range reported by [7 ] and [8 ], who reported that soil has electrical connection not exceeding $2 \mathrm{ml} \mathrm{mol} / \mathrm{cm}$ are considered suitable for cultivation.

Table 1. Chemical and physical propreties of soil.

\begin{tabular}{|c|c|c|c|c|c|c|c|c|c|}
\hline \multicolumn{3}{|c|}{ Mechanical analysis } & \multicolumn{2}{|c|}{$\mathrm{pH}$} & \multirow{2}{*}{ 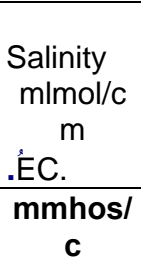 } & \multirow{2}{*}{$\begin{array}{c}\text { Active } \\
\text { Carbonate } \\
\text { CO3 } \\
\%\end{array}$} & \multirow{2}{*}{$\begin{array}{c}\begin{array}{c}\text { Total } \\
\text { Carbonate } \\
\text { CO3 }\end{array} \\
\%\end{array}$} & \multirow{2}{*}{$\begin{array}{c}\begin{array}{c}\text { Bicarbonate } \\
\text { HCO3 }\end{array} \\
\text { mea/l }\end{array}$} & \multirow{2}{*}{$\begin{array}{c}\text { Carbonate } \\
\text { CO3 }\end{array}$} \\
\hline $\begin{array}{c}\text { Sand } \\
\%\end{array}$ & $\begin{array}{r}\text { Silt } \\
\%\end{array}$ & $\begin{array}{c}\text { Clay } \\
\%\end{array}$ & $\begin{array}{c}\text { Patt } \\
\text { pH }\end{array}$ & $\begin{array}{l}\text { susp. } \\
\text { pH }\end{array}$ & & & & & \\
\hline 89,6 & 0,16 & 10,24 & 7,80 & 8.60 & 2.40 & 11.00 & 12,70 & 0,20 & 0.00 \\
\hline
\end{tabular}

Mean of principle stem length for wheat plant: The present results in table(2) and Fig.(1) showed continuously decreased in the mean length of principle stem for wheat plant cultivars, MBB and HD, with increasing the concentration of sea water.
Cultivar MBB exhibited resistant to salinity concentrations used more than that of HD cultivar, and this explain the increasing the mean value of plant length for MBB cultivar. The spraying with amelioratives growth (IAA and $\mathrm{GA}_{3}$ ), showed 
positively effect in reduction of the hurt effect of salinity on the mean of plant length at cultivars of $\mathrm{MBB}$ and HD. Also the spraying with $\mathrm{GA}_{3}$, showed increase in the mean of plant length more than that of IAA. These results are in agreement with the results obtained by [21 ], who stated that the spraying with amelioratives growth cause significantly effect in reduction of the hurt effect of salinity on different growth factors and explained the cleared effect with GA3 more than that of IAA, which agree with [10 ]. From these results it can be concluded that salinity has negatively effect on the means of plant length, but using of amelioratives growth (IAA and $\mathrm{GA}_{3}$ ), were decreased the hurt effect of salinity, particularly using $\mathrm{GA}_{3}$. These study also showed that the cultivar of plant has important role in affected with salinity, where the results showed that the cultivar MBB was surpassed in means of their stems length than plant of HD cultivar, under the concentrations of salinity used. This revealed that MBB cultivar showed resistant for salinity than HD cultivar.

Table 2. Leafy spraying effect with IAA and $\mathrm{GA}_{3}(2 \%)$ on vegetative growth for wheat plants (MBB, HD).

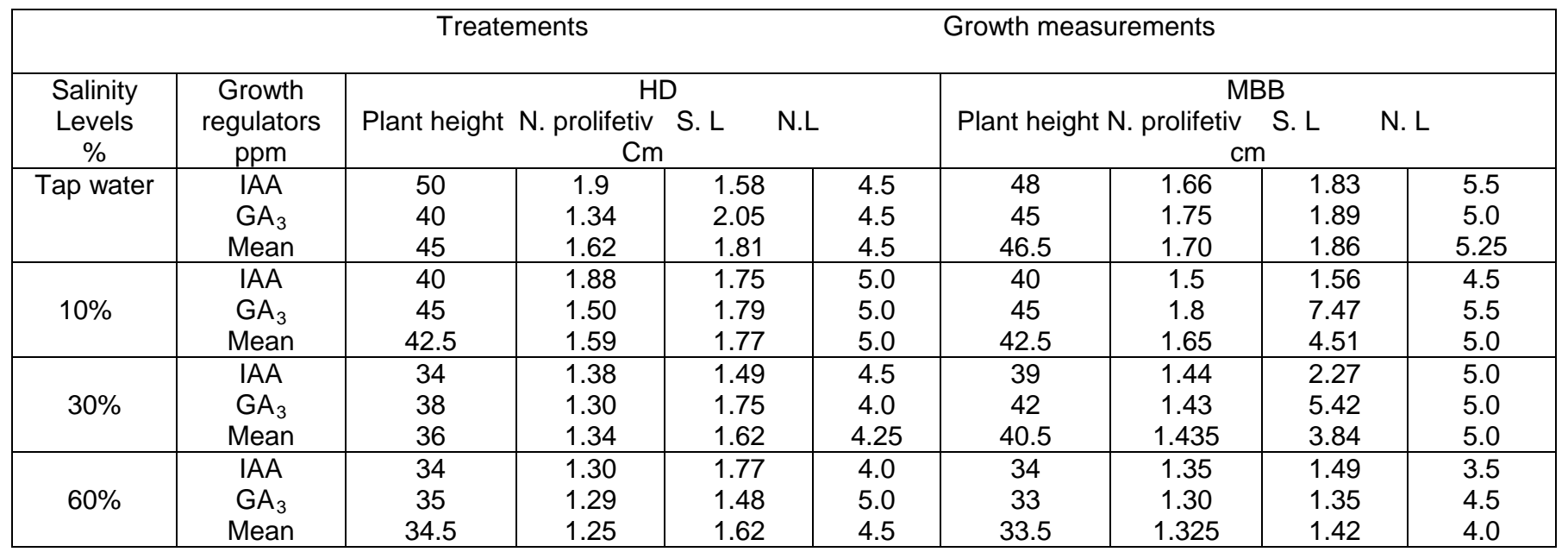

S.L:- surface of leaf

N.L:- number of leaves

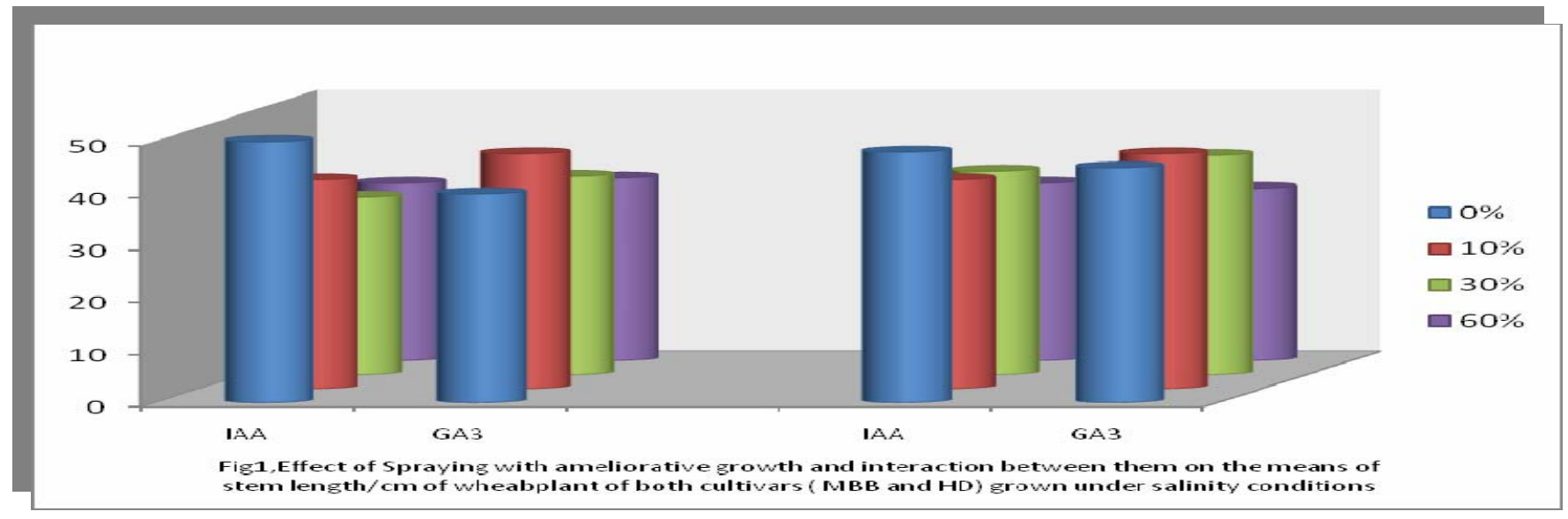




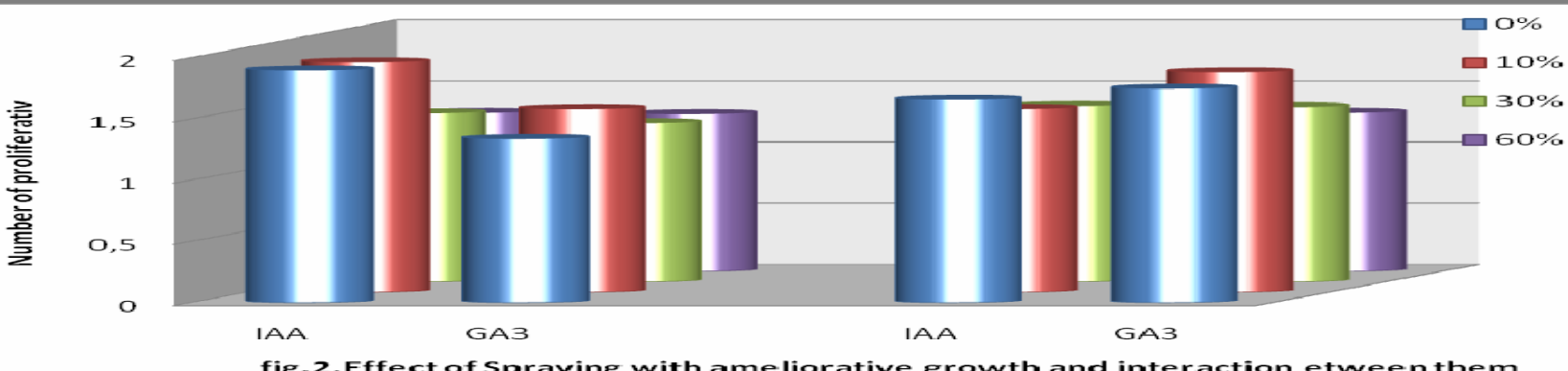

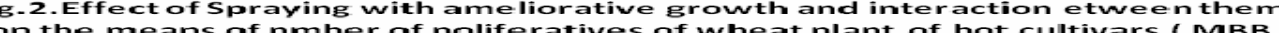
and HD, Erown under salinity condition

Table 3 - Effect of foliar application of IAA, GA3 and its interaction on the content of chlorophyll $a+b$ and in levels total proline in Triticum shoots under different salinity levels.

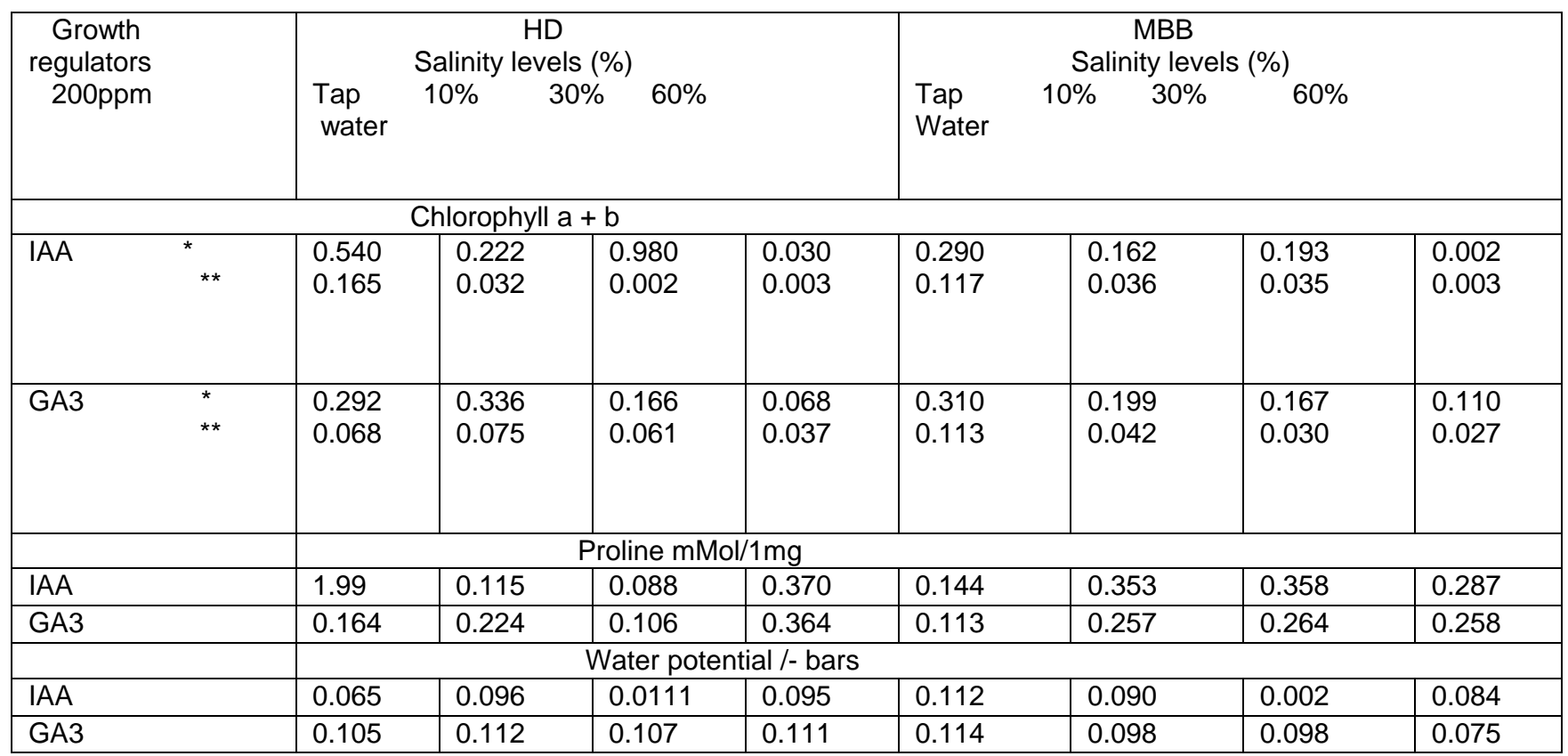

* Chlorophyll A

${ }^{* *}$ Chlorophyll b

\begin{tabular}{lcccc} 
LS.D at 5\% for:- & Chlorophyll A & Chlorophyll b & Proline & water potential \\
\cline { 2 - 5 } Salinity (S):- & 3.82 & N.S & N.S & N.S \\
Growth regulators (R):- & 7.46 & N.S- & 10.72 & N.S \\
Variete ( V ):- & 7.8 & N.S- & N.S & N.S \\
$(S) *(R):-$ & N.S & N.S & 0.2805 & .1703 \\
$(S) *(V):-$ & 2.28 & N.S & N.S & .3308 \\
$(V) *(R):-$ & 8.34 & N.S & N.S & .3320 \\
$S^{*} R^{*}$ V:- & 3.03 & N.S & N.S
\end{tabular}

NS $=$ Non significant.

Number of proliferates and leaf area of plant: From the results in table(2) and fig. $(2,3)$, it can be observed that the concentrations of salinity used having negatively effect on the number of leaves and proliferates of plant with increasing the concentrations of salinity. This observation agree with results of the mean of stems length of plant. These results also showed the effect of the spraying with IAA on HD cultivar, exhibited positively response to resistant the concentration of salinity used at the 
vegetative measurements of leaf area and length of principle stem of plant. The numbers of leaves and proliferates were affected negatively with increasing the concentrations of salinity, while the previous measurements were also affected for MBB cultivar. For spraying with $\mathrm{GA}_{3}$, the MBB cultivar showed negatively results as the higher concentrations of salinity, specially in stem length, leaf area and number of leaves and proliferates. Similar results were observed with HD cultivar, except leaves number was resistant to higher concentration of salinity.

Water potential for leaves of wheat plant: Results in table (3) and fig.(4) showed the effect of salinity treatments used on water potential of wheat plant leaves, irrespective of the effect of ameliorative growth (IAA and GA3), it can be observed that the water potential of leaves in plant, was decreased with increasing the salinity concentrations of sea water used in plant irrigation for MBB cultivar. The reverse was true for HD cultivar. The results also showed that the cultivar of HD was surpassed than cultivar of MBB. For the effect of interaction between salinity treatments and amelioratives growth on the mean of water potential of wheat plant, irrespective of plant cultivars, it can be observed that the using of ameliorative growth, sprayed on leaves of sum vegetative of plant leads to lowered in water potential of plant leaves with increasing the concentrations of sea water salinity for either of IAA or GA3. Results also showed the spraying with GA3 leads to increase water potential for leaves of plants more than that of IAA.

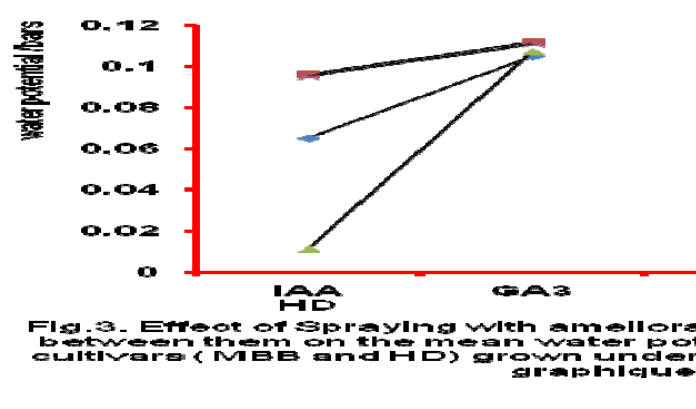

Determination of proline in leaves of wheat plant cultivars (MBB, HD): From the results presented in table(3) and fig.(5), it is clear that the amount of proline in leaves of both cultivars was affected by ameliorative growth as well as the cultivars of plant under different concentrations of salinity. For the effect of interaction between salinity treatments and amelioratives growth on the amount of proline in leaves of both cultivars of wheat plant, results showed the amount of proline was positively affected with increasing the concentrations of salinity, either for plants that treated with IAA or $\mathrm{GA}_{3}$. Similar observation was recorded for the effect of interaction between salinity concentration and cultivars of plant on the amount of proline. Irrespective of the effect of spraying with ameliorative growth, the MBB cultivar exhibited resistant to concentrations of salinity where the amount of proline in leaves of their plants was increased with increasing the concentrations of salinity. About the effect of interaction between plant cultivar and amelioratives growth on the amount of proline in leaves of wheat plant. It can be observed that HD was surpassed than MBB in increasing the proline content. Also the spraying with IAA had positively effect in increasing the amount of proline than those spraying with $\mathrm{GA}_{3}$. 


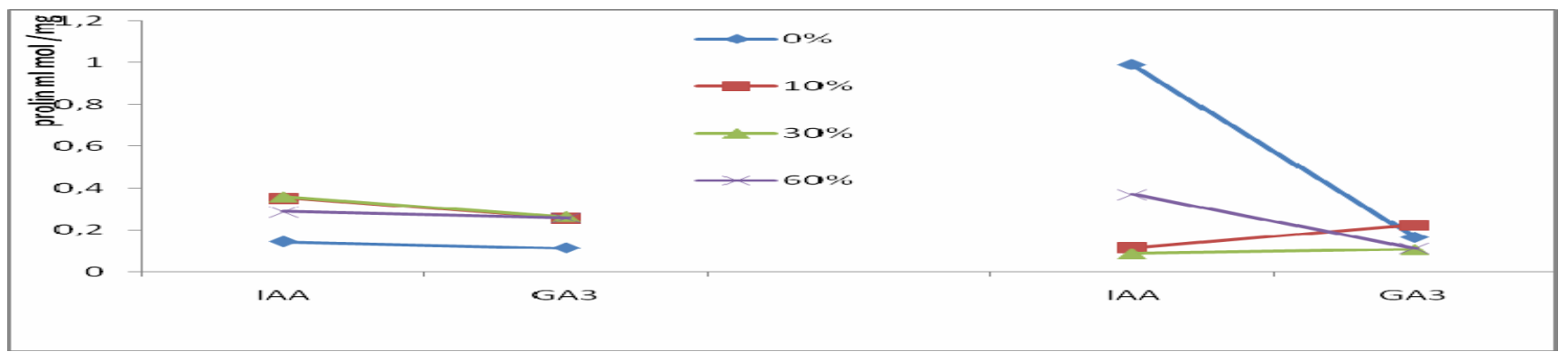

Fig 5: Effect of spraying with ameliorative growth and interaction between them on the mean proline content in leaves of wheat plant of both cultivars ( MBB and HD) grown under salinity conditions.

Plant content of chlorophylls ( $a, b$ ): The effect of salinity concentrations and spraying with ameliorative growth (IAA and $\mathrm{GA}_{3}$ ) on the amount of chlorophyll (a) in green part of wheat plant, irrespective of plant cultivar are shown in table(3) and fig.(6). The amount of chlorophyll (a) was affected negatively by concentrations of salinity used for irrigation with the plants that spraying with IAA or GA3. These results are consistent with results obtained by [21 ], who indicated that the increase concentrations of salinity had negatively effect on decreased the chlorophyll content in plant. For the effect of interaction between salinity and cultivar on the mean of chlorophyll (a) content, in green part of wheat plant, irrespective of the effect of amelioratives growth (IAA and $G_{3}$ ), if is clear that the concentrations of salinity had negatively effect on the amount of chlorophyll (a) and increase this effect at higher concentration of salinity (60\%). The present results showed that the cultivar has effect in increased or decreased in the amount of chlorophyll (a). Results obtained explained this effect, where HD cultivar was surpassed than MBB in the amount of chlorophyll (a), on the other hand, results of chlorophyll (a) were statistically analysed and they were significantly effect with all treatments as well as the interaction between them. Results in table(3) and fig.(6) illustrated the effect of interaction between salinity and cultivar on chlorophyll (b) content in the green part of plant, irrespective the effect of amelioratives growth (IAA and $\mathrm{GA}_{3}$ ). The concentrations of salinity used affected negatively on plant content of chlorophyll (b). Also, the using of amelioratives growth by spraying on green parts of the plant to decrease the hurt effect of salinity on plant, have not minimum role in slowing salinity effect. These results are similar to obtained by [18 ].

\section{The yield.}

\section{1.spikes weight.}

The effect of spraying with ameliorative growth and the interaction between them on spikes weight $(\mathrm{gm})$ pot for plant of wheat cultivars (MBB and HD), that grown under salinity condition are shown in table(4) and fig.(7). Irrespective of the effect of ameliorative growth, it is clear that HD cultivar

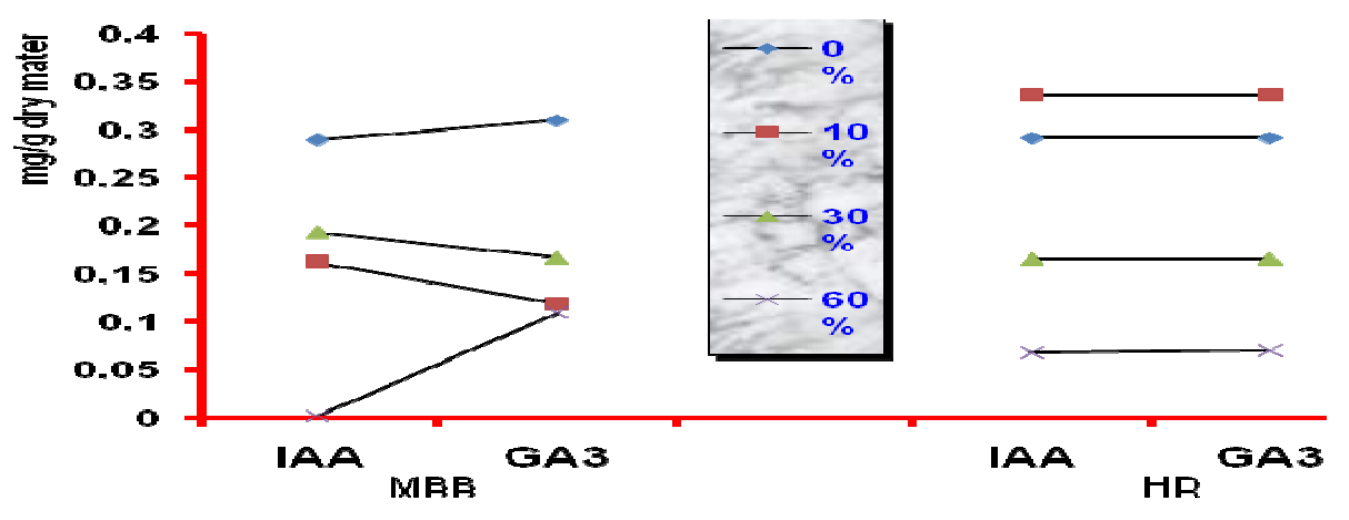

Chlorophyll A 
Agric. Biol. J. N. Am., 2011, 2(3): 512-521

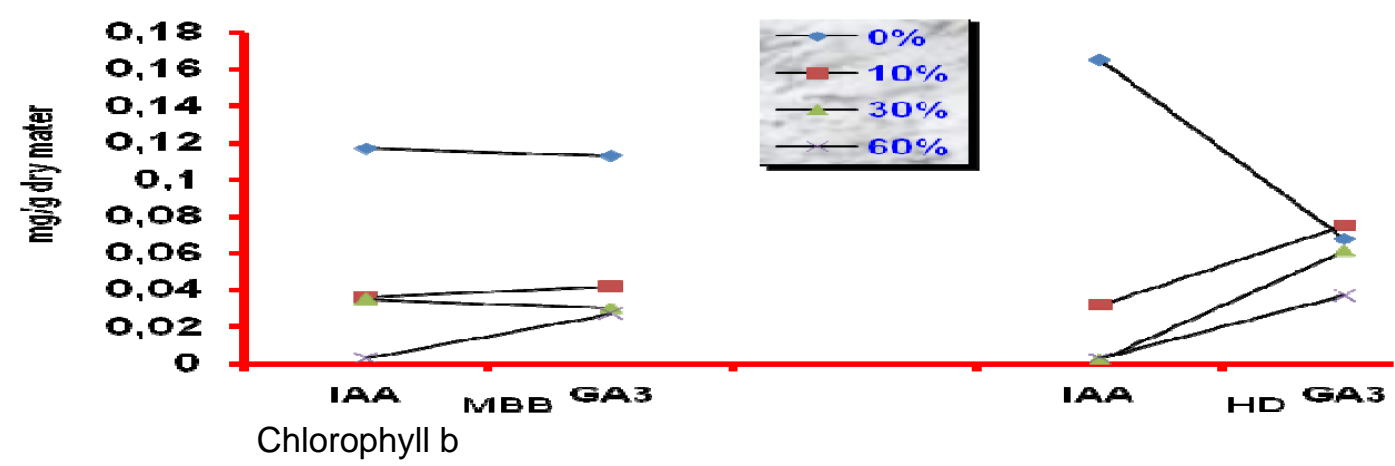

Fig 6: Effect of spraying with ameliorative growth and interaction between them on the mean chlorophyll A+ b content in leaves of wheat plant of both cultivars (MBB and HD) grown under salinity conditions.

exhibited resistant against concentrations of sea water as revealed in the increase of spikes weight with increasing the concentrations of salinity. Similar results were obtained with MBB cultivar, except higher concentration (60\%) of sea water was negatively effect on spikes weight. Moreover, MBB cultivar exhibited surpassed in spikes weight / pot under all salinity concentrations used than that of HD cultivar. For the effect of salinity treatments and ameliorative growth on spikes weight for plant of wheat cultivars, irrespective of the effect of cultivars of wheat plant. It is clear that the spikes weight was increased in treated plant with IAA and $\mathrm{GA}_{3}$ and salinity concentrations of $10 \%$ and $30 \%$ of sea water.
On contrast, negatively effect on spikes weight for both cultivars treated with either of IAA or GA3, was observed only at higher concentrations of salinity (60\%). Results also showed surpass of treated plant with GA3, in spikes weight, than that of treated plant with IAA table(4). About the effect of interaction between amelioratives growth and plant cultivars on spikes weight of both cultivars of wheat plant, the MBB cultivar was surpassed than HD cultivar, particularly increasing of spikes weight/pot in treated plant with ameloratives growth (IAA and $\mathrm{GA}_{3}$ ). The present results showed that plant treated with $\mathrm{GA}_{3}$ was surpassed in spikes weight than that of treated with IAA.

Table 4 :- Effect of foliar application of IAA GA . $(200 \mathrm{ppm})$ and its interaction on grains yield of Triticum plants grown under different salinity levels .

\begin{tabular}{|c|c|c|c|c|c|}
\hline \multirow{2}{*}{\begin{tabular}{|l|}
$\begin{array}{l}\text { Salinity } \\
(\%)\end{array}$ \\
Controle
\end{tabular}} & \multirow{2}{*}{$\begin{array}{l}\text { growth } \\
\text { Regulators } \\
\\
\text { IAA } \\
\text { GA3 } \\
\text { Mean }\end{array}$} & \multicolumn{2}{|c|}{$\begin{array}{l}\text { HD } \\
\text { Weight of } \\
100 \text { grains/g Spikes Weight }\end{array}$} & \multicolumn{2}{|l|}{$\begin{array}{l}\text { MBB } \\
\text { Weight of } \\
\text { 100Grains/g }\end{array}$} \\
\hline & & $\begin{array}{l}3.90 \\
4.00 \\
3.95\end{array}$ & \begin{tabular}{|l|}
4.40 \\
5.50 \\
4.95
\end{tabular} & $\begin{array}{l}4.20 \\
4.40 \\
4.30\end{array}$ & $\begin{array}{l}7.03 \\
6.66 \\
6.84\end{array}$ \\
\hline $10 \%$ & $\begin{array}{l}\text { IAA } \\
\text { GA3 } \\
\text { Mean }\end{array}$ & $\begin{array}{l}3.500 \\
4.10 \\
3.80\end{array}$ & \begin{tabular}{|l|}
5.93 \\
5.93 \\
5.93
\end{tabular} & $\begin{array}{l}4.50 \\
4.40 \\
4.45\end{array}$ & $\begin{array}{l}7.20 \\
6.33 \\
6.76\end{array}$ \\
\hline $30 \%$ & $\begin{array}{l}\text { IAA } \\
\text { GA3 } \\
\text { Mean }\end{array}$ & $\begin{array}{l}3.60 \\
3.80 \\
3.70\end{array}$ & $\begin{array}{l}5.60 \\
6.00 \\
5.80\end{array}$ & $\begin{array}{l}4.70 \\
4.60 \\
4.65\end{array}$ & $\begin{array}{l}6.93 \\
7.16 \\
7.04\end{array}$ \\
\hline $60 \%$ & $\begin{array}{l}\text { IAA } \\
\text { GA3 } \\
\text { Mean }\end{array}$ & $\begin{array}{l}3.60 \\
3.50 \\
3.55\end{array}$ & $\begin{array}{l}5.33 \\
4.73 \\
5.03\end{array}$ & $\begin{array}{l}3.30 \\
3.30 \\
3.30\end{array}$ & $\begin{array}{l}4.20 \\
4.86 \\
4.53\end{array}$ \\
\hline
\end{tabular}




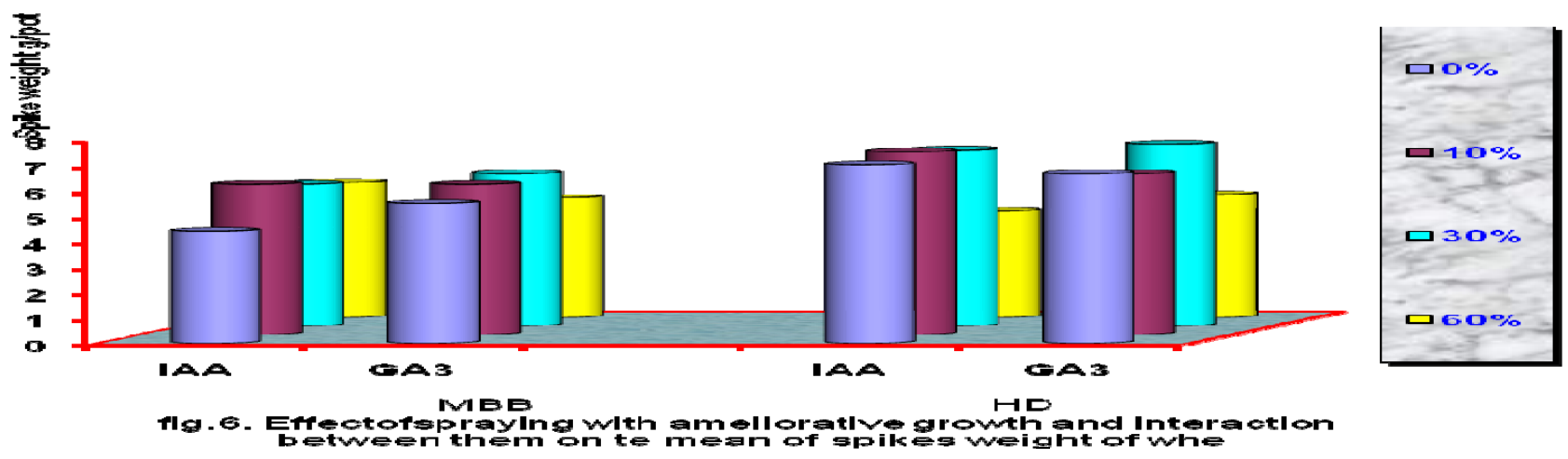

\section{2 - 100 wheat grain weight.}

Results in table(4) and fig.(9) stated the increase of the concentrations salinity of sea water has negatively effect on 100 wheat grain weight in both wheat plant cultivars ( $\mathrm{MB}$ and $\left.\mathrm{GA}_{3}\right)$. Similar effect was observed with ameliorative growth (IAA and $\left.\mathrm{GA}_{3}\right)$. For the effect of the interaction between salinity treatments and cultivars (MBB and $\mathrm{GA}_{3}$ ) on 100 wheat grain weight, irrespective of the effect of amelioratives growth. The results showed that the weight of 100 grain was increased for MBB cultivar at concentrations of $10 \%$ and $30 \%$, while negatively effect was observed at concentration of $60 \%$. The weight for 100 grain for HD cultivar was affected under all salinity concentrations used. Results also showed that MBB cultivar was higher response for spraying with amelioratives growth (IAA and $\mathrm{GA}_{3}$ ) compared with $\mathrm{HD}$ cultivar. For the effect of interaction between ameliorative growth on weight of 100 wheat grain irrespective of the effect of salinity treatments, the results showed that the use of $\mathrm{GA}_{3}$ sprayed on leaves, leads to increase the weight of 100 weight grain more than using of IAA. Also the MBB cultivar was favorite and surpassed in increasing the 100 wheat grain weight than HD cultivar under each of IAA and $\mathrm{GA}_{3}$.

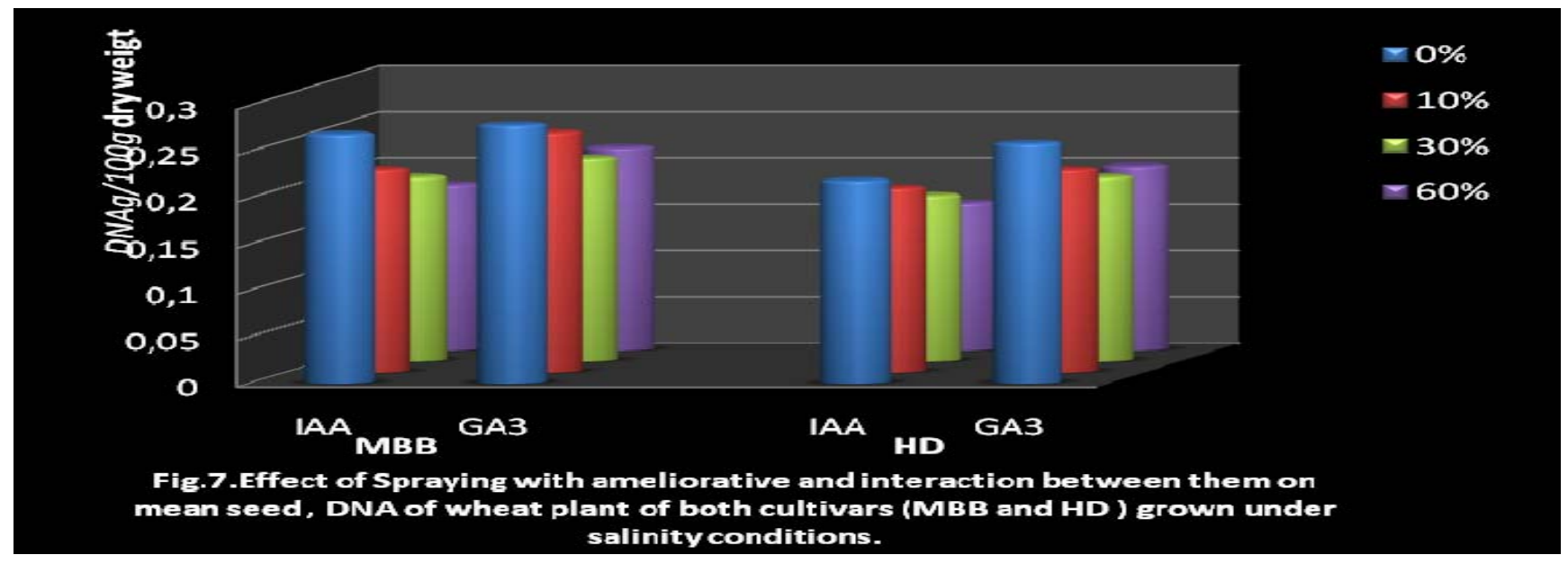




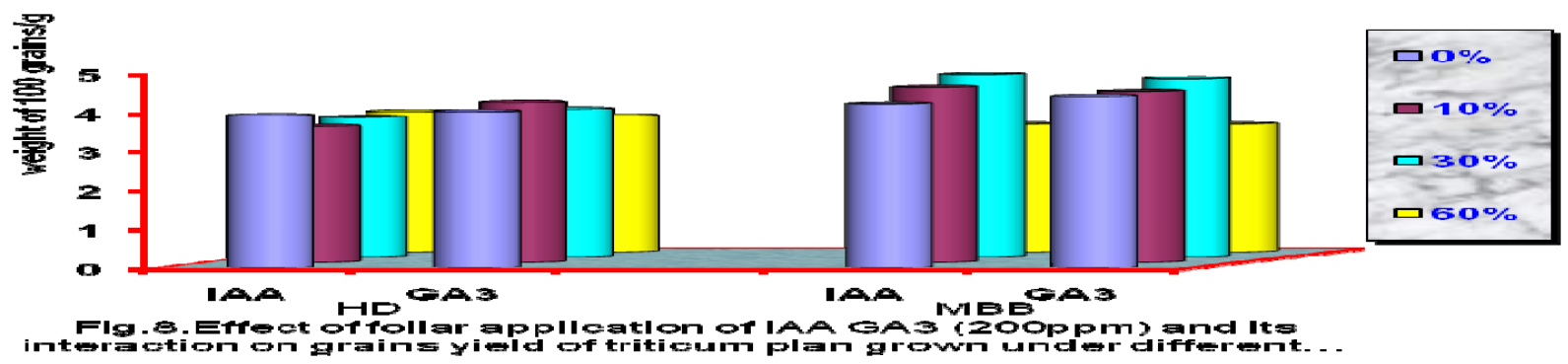

\section{1- Nucleic acid levels in wheat seeds from both cultivars (MBB and HD).}

The effect of interaction between ameliorative growth and salinity concentrations on the amount of nucleic acids (RNA and DNA) in seed of wheat plant are shown in table(5). And Fig(7-8) It can be observed that the increasing of salinity concentrations and ameliorative growth cause negatively effect on the level of DNA specially at higher concentration (60\%), while positively effect was observed on the level of RNA specially at concentrations of $10 \%$ and $30 \%$. Results also showed the amount of RNA was increased in both cultivars (MBB and HD), while DNA amount were decreased in both cultivars under all salinity treatments. These results are in accordance with those reported by [21 ]. For the effect of interaction between salinity treatments and plant cultivars (MBB and $H D$ ), irrespective of the effect of ameliorative growth, on the amount of nucleic acids, the results showed increase in the amount of RNA at salinity concentrations of $10 \%, 30 \%$ and slightly decreased at higher concentration $60 \%$. On contrasts the amount of DNA was decreased with all salinity concentrations used in both cultivars under the present study (MBB and HD). The MBB cultivar was surpassed than HD cultivar in the levels of total nucleic acids at different salinity concentration, particularly RNA amount. These results are consistent with the results obtained by other workers [22 ], [18], [21 ]. About the effect of the ameliorative growth and plant cultivars on the amount of nucleic acids, irrespective of the effect of salinity concentrations, the results also showed that seeds of wheat plant spraying with $\mathrm{GA}_{3}$ exhibed increase in nucleic acids content, particularly RNA, than that of spraying with IAA. Also the MBB cultivar was surpassed in the level of total nucleic acid than that of $H D$ cultivar when they were spraying either with $\mathrm{GA}_{3}$ or IAA. These results are in accordance with those reported by [12 ], [10 ], [16 ], [21 ] and [8 ], who reported that the spraying with oxin and gebrilin leads to stimulate the synthesis of nucleic acid (RNA) and protein in wheat plant. Thus, the MBB cultivar was more resistant against salinity treatments and positively response to ameliorative growth $\left(G A_{3}\right.$ and IAA), than that of HD cultivar.

Table 5: effect of spraying with ameliorative growth (IAA and $\mathrm{GA}_{3}$ ) at level of $2 \%$ and interaction between them on the level of nucleic acids (RNA, DNA)in seeds of wheat plant (MBB, HD) under different concentration of salinity).

\begin{tabular}{|c|c|c|c|c|c|}
\hline \multirow[t]{2}{*}{ Salinity \% } & \multirow{2}{*}{$\begin{array}{l}\text { Aliorative growth } \\
\text { and means }\end{array}$} & \multicolumn{2}{|c|}{ MBB cultivar } & \multicolumn{2}{|c|}{ HD cultivar } \\
\hline & & DNA & RNA & DNA & RNA \\
\hline $0 \%)$ & $\begin{array}{c}\text { IAA } \\
\mathrm{GA}_{3} \\
\text { Mean }\end{array}$ & $\begin{array}{l}0.27 \\
0.28 \\
0.26\end{array}$ & $\begin{array}{l}2.46 \\
2.76 \\
2.61\end{array}$ & $\begin{array}{l}0.22 \\
0.26 \\
0.24\end{array}$ & $\begin{array}{c}2.30 \\
2.5 \\
2.40\end{array}$ \\
\hline $10 \%$ & $\begin{array}{c}\text { IAA } \\
\mathrm{GA}_{3} \\
\text { Mean }\end{array}$ & $\begin{array}{l}0.22 \\
0.26 \\
0.24\end{array}$ & $\begin{array}{l}2.51 \\
2.83 \\
2.67\end{array}$ & $\begin{array}{l}0.20 \\
0.22 \\
0.21\end{array}$ & $\begin{array}{l}2.46 \\
2.60 \\
2.53\end{array}$ \\
\hline $30 \%$ & $\begin{array}{c}\text { IAA } \\
\mathrm{GA}_{3} \\
\text { Mean }\end{array}$ & $\begin{array}{l}0.20 \\
0.22 \\
0.21\end{array}$ & $\begin{array}{l}2.55 \\
2.91 \\
2.73\end{array}$ & $\begin{array}{l}0.18 \\
0.20 \\
0.19\end{array}$ & $\begin{array}{l}2.48 \\
2.72 \\
2.60\end{array}$ \\
\hline $60 \%$ & $\begin{array}{c}\text { IAA } \\
\mathrm{GA}_{3} \\
\text { Mean }\end{array}$ & $\begin{array}{l}0.18 \\
0.22 \\
0.22\end{array}$ & $\begin{array}{l}2.20 \\
2.40 \\
2.30\end{array}$ & $\begin{array}{l}0.16 \\
0.20 \\
0.18\end{array}$ & $\begin{array}{l}2.12 \\
2.28 \\
2.20\end{array}$ \\
\hline
\end{tabular}

.(Means of 2 samples $\mathrm{g} / 100 \mathrm{~g}$ dray weight 


\section{REFERENCES}

[1]Aly,F,A.A.(1999) :Ecological and eco - physiological studies on aera javanica ( Burm.f.) Spring,Bull.fae .Agro.Cairo Univ.50,436-459

[2] Bishop and Maceadern (1971): Response of spring wheat and barly to nitrogen phosphorus and potassium. Canadian Journal of Soil Science. Vol, 51Feb.(71) ${ }^{\circ} 1$.

[3] Black, C. A. (1965):Methods of soil analysis part 1,2: chemical and microbioloical

properties. Amer. Soc. of Agro . Inc. Pub., Madison Washinton.U.S.A.

[4] Bonner, J. (1933): The action of the plant growth hormone. J. Gen. physiol.1763: .

[5] Brown, R. W.,Van Haversen. (1971): Psychrometry in water relations research, proceedings of the symposium on thermocuple psychrometers. Agr. Exp. Stat.,

Utra State University.

[6] Bruisma, J. (1961): A comment on the spectrophotometric determination of chlorophyll. Biochem. Biophys. Acta. 52:576 -578.

[7] Chapman, H .D. and Pratt, P .F. ( 1971): Methods of Analysis for soils, plants and waters.Univ. of California, Division of Agric. Sci. Barkely, Calif.

[8]EL-Mohandes,M.A.o.(1999)The Use of associative diazotrophs With different Rates of nitrogen fertilization and Compost to enhance growth and N2 fixation of Wheat .Bull.Fac.Agric.Cairo.Univ-50,729-754

9] Fiszan-Szarfarz, B, Szarfarz, O. and Guevara. de Murillo, A. (1981). A general fast and sensitive micro method for DNA determination: Application to rat and mouse liver, Rat Hepatoma, Human leucocytes, Chicken fibroblasts and yeast cell. Analyt. Biochem. 110, 165-170.

[10] Harder, R. and R. Bünsow. (1956): Einfluss des Gibberellins auf die blütenbildung beikalanchoë blossfeldiana.Naturwissenschaften 43:544.

[11] Kilmer, V.J. And Alexander, L.T. (1949): Methods of Making Mechanical Analysis of soil. Sci. 68:15.

[12] Masuda,Y. , E. Tanimoto, and S. Wada. (1967): Auxin-
Stimulated RNA syntesis in Oat coleoptile cells. Physiol Plant. 20:713.

[13] Materiaux (1954): Contribution à I étude de I ànalyse granulometrique

Ann Agr.Serie A.I. Page 89-205.

[14] Mc Neal, F. H., Berg, M.A., Brown,P.L., and Mc Guive,C.F. (1971): Genotypes. Productivity and quality response of fine spring wheat Triticum aestivum $L$. to nitrogen fertilizer. Agro. Journal. 63 (6): 908 -910.

[15] Mejbaum, W. (1939). Estimation of small amounts of pentoses, espicially of derivatives adenylic acid. Z. Physiol.Chem. 258, 117.

[16] Phinney, B.O., and C.A. West. (1961): Giberellins and plant growth. in W. Ruhland, Ed., Encyclopedia of Plant Physiology. 141185: .

[17] Richards, L.A. ( 1954): Diagnosis and improvement of saline and Alkali soil

Agron. Hand Book, N 60 U.S. Dept of Agro.

[18] Sacher, J.A. (1967): Senescence action of Auxin and Kinetin in control of RNA

and protein synthesis in subcellular fraction of Bean endocarp. Plant Physiol. 421334 : .

[19] Saheh, S.A., El-Deeb, M.A. and Ragab, A.A. (2000). Response of Faba bean ( Vicia faba L.) to rhizobium inoculation as affected by nitrogen and phosphorous fertilization. Bull. Agri. Cairo Univ. 51, 17-30

[20] Sallam, H. A. (1993):Foliar Application of IAA and Ndressing as well as interaction effects on cowpea plant grown under wadi sudr conditions. Egypt. J. Appl. Sci. 8(7):726-738.

[21] Sallam, H. A.,And Samia, M. Sabah. (1993): Foliar application of IAA and a well as interaction effects growth, yield and some biochemical composition of guar plant under saline conditions. Annals of Agric. Sci. Moshtohor, Vol.31(3).

[22]Saleh, S.A.,El-dob, M.A.and Ragab, A.A .(2000) Response of faba been ( Vicia faba L-) to Rhizobium inoculation as affected by Nitrogen and Phosphorus fertilization .Bull.Fac.Aagric.Cairo.Univ-51,17-30

[23] Shimoda, C., Y. Masuda and N. Yanagishima. (1967): Nucleic Acid metabolism involved in Auxin-induced elongation of yeast. Cells Physiol. Plant. 20299 : . 